\title{
DISCOURSES SHAPING HUMAN RIGHTS EDUCATION RESEARCH IN SOUTH AFRICA: FUTURE CONSIDERATIONS
}

\author{
S. Simmonds* \\ Research Unit for Education and Human Rights in Diversity (Edu-HRight) \\ e-mail: shan.simmonds@nwu.ac.za \\ P. du Preez* \\ Curriculum Studies \\ e-mail: petro.dupreez@nwu.ac.za
}

*North-West University

Potchefstroom, South Africa

\section{ABSTRACT}

Human rights education is critiqued for being traditionalist and conceptually imprisoned. This view stems from the distrust in its ability to transform deeply rooted injustices and inequalities etched within South Africa's society. There is therefore an outcry to reimagine human rights education. For this article it is important to understand how and why human rights education discourses in South Africa have come to be framed by some scholars in this way and to contemplate where the discourse might be heading in the future. We reviewed doctoral theses in the field of Education which claim to engage with and make contributions to human rights education research. We found that human rights education discourses have been (and are being) shaped in South Africa in terms of three distinct phases: inception, growth, and cynicism. It became evident from the findings that human rights education research is predominantly school-based and fundamentally descriptive and uncritical. To conclude, we reflect on these findings so as to put forward future considerations for human rights education research.

Keywords: human rights education research, doctoral theses, post-school education and training

\section{INTRODUCTION}

Globally, the scholarship of human rights and human rights education has increased exponentially since the 1970s (Suarez and Ramirez 2004). Keet (2015, 46-47) explains:

As right articulations have come to drench the globe over the past six decades, human rights violations became the prevailing expressions of structurally anchored inequalities in social, economic, cultural, political and environmental spheres. These challenges range from poverty, hunger, discrimination of all sorts, wars and conflict, political instability, environmental degradation, social fragmentations on national and international levels, unequal global arrangements, authoritarian regimes, the decadence of wealth, and the survivalist struggles of poor communities on a daily basis. 
Chingono and Nakana $(2009,404)$ describe human rights in southern Africa as 'endangered in a few SADC countries'. This is partly because states 'pursue economic objectives that conflict with their human rights obligations' (Gammage 2014, 779). Keet $(2014,148)$ argues that this situation is the result of the collapse of human rights into neo-liberalism and an associated 'emergence of human rights markets'. South Africa, unlike other SADC countries, has embraced human rights discourse since the formal ending of the system of apartheid in 1994 (Mubangizi 2015). That is not to say that the country acts against human rights violations, but merely that it has embraced the discourse of protection and promotion of human rights. Human rights education and human rights in education ${ }^{1}$ have been central to the protection and promotion of human rights in South Africa. National school and post-school curricula, governance and structures proclaim to endorse their content and approaches with human rights principles and ideals as these remain the moral language for the public good. However, although human rights education is professed to be the cornerstone of human rights protection and promotion, it has been inclined to prize an epistemological approach to human rights, relying largely on the rational, intellectual mind and less so on a moral and ethical one (Du Preez, Simmonds and Roux 2012). For Keet $(2012,7)$ this is because the human rights education field is 'conceptually imprisoned ... conservative and unproductive'. It is not critical of the hegemonic discourses and counteractive tautologies that subsume mindless human rights idolatry. There is, therefore, a cry to reimagine human rights education as 'a space for contestation, contention, disputation, public debate and social engagement' (Keet 2012, 9).

It is important to understand how and why human rights education discourses in South Africa have come to be framed by some scholars in this way and to contemplate where the discourse might be heading in the future. The article proceeds with a review of doctoral theses in the field of Education which claim to engage with and make contributions to human rights education research. It was deemed meaningful to review these theses since they should reflect trends and identify intellectual and theoretical advancements in this field, both current and future. We found that human rights education discourse has been (and is being) shaped in South Africa in terms of three distinct phases: inception, growth, and cynicism. To conclude, we reflect on future considerations for human rights education research.

\section{HUMAN RIGHTS EDUCATION RESEARCH: CONTRIBUTIONS MADE BY DOCTORATES}

The contributions made by doctorates to human rights education research are regarded as noteworthy since they are at the forefront of new knowledge development. Reviewing human 
rights education research done by doctoral candidates in the field of Education enabled us to develop an understanding of some of the key trends in this field. We approached the theses as conceptual research and reviewed them as literary works. To consider how human rights education has taken shape in the democratic South African landscape, doctoral theses completed from 1994 were reviewed. Using the Sabinet database we were able to search the titles of theses completed in the field of Education that included right(s) (reg(te)), human right(s) (mensereg(te)) and/or human rights education (menseregte-onderwys). We opted to focus on the titles since these concepts were clearly central to the theses. Through Sabinet we were able to access a small-scale sample of 10 theses completed between 1994 and 2012. Of these 10 theses, one had to be disqualified because it was based on human rights education in Kenya and not in South Africa. Owing to the incompleteness of the Sabinet database from 2013 onwards, this period proved most fitting and enabled us to obtain the full text of the theses. As a review presents descriptive accounts of the phenomenon under study we paid attention to what the theses claimed as their main contribution to human rights education research.

Employing chronology, Viljoen's (1999) thesis entitled 'The influence of a culture of human rights on the management style of the school principal' (Die invloed van 'n menseregtekultuur op die skoolhoof se bestuurstyl) focused on the role of the school principal and the management team in developing a management style that nurtures a culture of human rights. The literature viewed human rights in schools through the lens of a Christian perspective and sought to explore the influence of a human rights culture on religious observance. However, precisely what was meant by the notion of a 'human rights culture' is never explicitly stated. The findings highlight the need for principals to create a culture of human rights in their schools and to nurture this culture in their management styles. Viljoen (1999) identifies the need for further research on multiculturalism, religious diversity and racial integration in schools from an education management perspective. This study was completed five years after the apartheid system was abolished and should be understood in that time and space. It aimed to raise awareness of the implications of human rights in education. The Christian perspective should also be viewed in context of its hegemony at the time. Three years later, Ndlala (2002) and Alston (2002) completed their human rights education research.

Both theses resonate with the discipline of education law and intersect with education management, which is not uncommon as legal methods and approaches are often applied to education policy and management contexts (De Wet 2014, 34). Ndlala's (2002) thesis, 'The senior education manager's legal right to professional development', aimed to create awareness amongst senior education managers with regard to the legal right to professional development 
based on labour law policies. A quantitative survey design research approach was used and questionnaires were administered to senior education managers (such as subject specialists and circuit managers) at provincial departments of education. The research findings highlighted that the provision of relevant professional development courses to senior managers is one of the important factors affecting the improvement of management performance and the quality of service delivery in education. This echoes the principles entrenched in the South Africa Council for Educators Act No. 31 (South Africa 2000) which provides for continued professional development to promote and develop the education and training profession.

Alston (2002) focussed on the implementation of and access to the right to freedom of expression and how school management should deal with this matter. The thesis is entitled 'The constitutional right to freedom of expression: An exploration of its relevance to the South African school community'. In conducting case law research involving law reports from South Africa, the United States of America, Canada, England and New Zealand, Alston (2002) investigated freedom of expression in terms of hairstyles, dress, jewellery, press freedom, artistic creativity and academic freedom. One of the main findings was that the implementation of and access to the right to freedom of expression is affected by prevailing cultural and religious values in different countries, resulting in a universally proclaimed right not being universally applied (ibid., 377). McCowan’s (2010, 510-511) view is that '[u]niversal rights are primarily moral rather than legal rights, although they have official status through nonbinding declarations such as the UDHR, and in some cases (such as in the United Nations Convention on the Rights of the Child (CRC)) they are turned into legally binding treaties'. This might explain why different countries acknowledge these universal rights but cannot apply them universally because of the unique diversity (cultural, ethical, religious and so forth) underpinning the moral and ethical make-up of each country.

Engaging with the access debate, Gamede's (2005) research focussed on 'The biography of "access” as an expression of human rights in South African education policies'. In particular, the complexities of access to education as a human right are discussed and the unevenness of physical and epistemological access problematised. The research found little in the way of policies on 'equality of access' to education. However, there was no evidence that the researcher had consulted the policy document on improving access to free and quality basic education although it was published by the Department of Education in June 2003 (Department of Education 2003b); two years prior to the completion of this thesis. Nevertheless, this qualitative research in the field of history of education included the voices of political and educational leaders, principals, teachers and learners in secondary schools so as to reflect the complexities 
of human rights education.

With the emphasis on the legal rights of learners, the research by Van Vollenhoven (2006) and Joubert-Serfontein (2007) took centre stage in the discipline of education law. Van Vollenhoven's (2006) thesis addressed one specific legal right: 'Learners' understanding of their right to freedom of expression in South Africa'. Van Vollenhoven $(2006,7)$ explains that there are two reasons that research on freedom of expression has gained so much attention: one is that the traditionally authoritarian culture of South Africa tends to silence citizens; and the other is that the development of a national culture of human rights has encouraged citizens to exercise their right to freedom of expression. After conducting a qualitative study with Grade 11 learners, his research found that learners do not know how to exercise the right to freedom of expression because they hold narrow conceptions of this right; they absolutise the right and do not understand the limitations of the right. Contributing to human rights education, research on how learners depict their right to freedom of expression seems to be important considering the various protest actions in which some learners participate. It also proves fitting in light of the Promotion of Equality and Prevention of Unfair Discrimination Act of 2000. Entitled 'The fundamental rights of learners within inclusive education: an educational-juridical perspective', Joubert-Serfontein's (2007) research accentuates learners' fundamental right to inclusive education in the light of various human rights policies and the Education White Paper 6 (Department of Education 2001a). Using a comparative education law methodology this research set out to determine the fundamental rights of learners in an inclusive education setting. Employing international benchmarking, South Africa was compared to the United States of America and the United Kingdom. One of Joubert-Serfontein's (2007) key findings was that equal access to education must not be seen as synonymous with quality education. Overall, in South Africa, inclusive education remains a vision for the future because of the many challenges it still needs to grapple with.

In 2007, the discourse changed when Keet raised concerns about human rights, both in terms of research and in education in general. The main finding of this conceptual, historical inquiry was that human rights are a totalising grand narrative when viewed from a postmodern perspective. This narrative influences how human rights education is conceptualised and inevitably affects our fundamental understanding thereof. This study explicitly argues that human rights are under-theorised and that they require alternative theorisation, independent of universal, normative standards. Although Keet (2007) rigorously critiques mainstream conceptions of human rights, his suggestion on how to reconceptualise human rights education reveals his admiration for the mobilising potential of human rights in the field of education. He 
suggests theorising human rights education in terms of critical pedagogy within a postmodern framework. Such an approach calls for researching human rights education to envisage an alternative pedagogical language that problematises social justice, human needs, suffering and solidarity as well as what the nature of human rights, as antideclarationist, perspectivist, particularist and universalist, entails for education. This echoes Dembour's $(2010,4)$ view that if 'human rights exist only because people talk about them' and not because people 'believe in' them, this creates opportunities for human rights education to contest and reimagine human rights.

Employing a qualitative case study, Netshitahame (2008) explored how learners understand human rights and especially their right to education. This education law research proves that it is vital for human rights education to create an awareness of the duties and responsibilities of the legal rights of learners. Struthers (2015, 57-58) sees human rights education as dealing not only with 'factual content' but also with the 'personal reality' that it has for the lives of individuals. When unlocking these realities Netshitahame (2008) found that some learners did not know how to exercise their rights, especially their right to education. As such, some learners found it difficult to deal with dilemmas where the exercising of their right to education was in conflict with the rights and duties of school authorities. The research has contributed to a deeper knowledge and understanding of how learners interpret and implement their right to education.

With a focus on dialogue as a facilitation strategy to infuse the classroom with a culture of human rights, Du Preez (2008) employed qualitative participatory intervention research to develop a professional development programme for in-service teachers. This research promoted a dialogic stimulus to allow for moments of deconstruction, critique and reconstruction so as to conceptualise the possibilities and challenges for infusing a culture of human rights into the classroom at a moral level rather than at an epistemological level. One way to do this is through what Du Preez (2008) regards as ethical communities, which provide the propensity to anthropomorphise the ideal of infusing a culture of human rights through dialogue. For Tibbitts and Kirchschlaeger (2010) research commonly focuses on either one or a combination of the theory, implementation or outcomes of human rights education. The pedagogical and methodological promise of dialogue as a facilitation strategy to foster a culture of human rights in the classroom was central to this research.

The prominence of research on the principles of human rights, largely from an education law perspective, seem fitting in the context of South Africa's young democracy, and in view of the crucial role that the legal system has played in transforming the education system (Asmal 
and James 2002). Creating awareness, skills and attitudes through curriculum content and teaching-learning, while simultaneously ensuring that all stakeholders are involved, especially those in management and leadership were also key foci in the theses. Across all the doctoral theses, the suggested beneficiaries of the research findings were education authorities (department of education and government), national policy makers, teacher training programme and curriculum developers, school communities (teachers and learners) and management (principals and other senior education managers). These are all key role players of the schooling sector and could reaffirm the emphasis placed on these role players to develop, implement and promote human rights education.

\section{THREE PHASES OF HUMAN RIGHTS EDUCATION RESEARCH: INCEPTION, GROWTH AND CYNICISM}

The review revealed three distinct phases, i.e. inception, growth, and cynicism, in human rights education research in South Africa. The Truth and Reconciliation Commission (TRC) and the first democratic Constitution, which contains the Bill of Rights, marked the inception phase of human rights. Addressing the human rights violations that occurred during the apartheid era was a necessary part of dealing with the injustices of the past. A first step was the 1996 Constitution and Bill of Rights. Another step was the establishment of the TRC by Parliament in 1995 under the Promotion of National Unity and Reconciliation Act No. 34 of 1995. The purpose of the TRC was to lead to knowledge of the causes, nature and extent of human rights violations of the past that could ultimately lead to acceptance, tolerance and reconciliation in the future (Gibson 2004). In South Africa 'the truth and reconciliation process was successful at exposing human rights abuses by all sides in the struggle over apartheid - thereby contributing to the country’s collective memory about its apartheid past' (Gibson 2004, 207). Admitting to human rights abuses was an important first step in the process of seeking truth and working toward reconciliation. This act of exposure had to be followed by a pro-active approach to raise awareness of the extent and scope of human rights applications. For example, it was no longer enough to speak out about the unjust nature of the apartheid education system; it was necessary to make equitable access to education a reality (Du Preez 2012). The access with success debate marked research at the time (and is still a matter of academic concern), but also received attention in policy documents such as the South African Schools Act (Department of Education 1996), the Education White Paper 3 (Department of Education 1997) and the Education White Paper 6 (Department of Education 2001a). The discourses marking the inception phase were evident in the research conducted by Viljoen (1999) which promotes more 
equitable management in schools as well as by Gamede (2005) who engages with the access debate as a key feature of human rights in South Africa.

The majority of the theses that we analysed (Alston 2002; Ndlala 2002; Van Vollenhoven 2006; Joubert-Serfontein 2007; Du Preez 2008; Netshitahame 2008) fall under the growth phase of human rights education in South Africa. They were a response to the rapid increase in the number of policies that address aspects related to human rights education in the school context and the challenges that schools experienced in dealing with these aspects during the early stages of post-apartheid. These various documents and reports, that most commonly stem from initiatives from the South African Department of Education, support the inclusion of human rights in the curriculum and pedagogy in general as a component of education for citizenship and as a means of infusing the classroom with a culture of human rights. These include: the National Conference Report, SAAMTREK: Values, Education and Democracy in the 21st Century (Department of Education 2001b), the Manifesto on Values, Education and Democracy (Department of Education 2001c), the School-based Research Report on Values, Education and Democracy (Department of Education 2002), the Framework on Values and Human Rights in the Curriculum (Department of Education 2003a), Values and Human Rights in the Curriculum: A Guide (Department of Education 2005), and the Bill of Responsibilities for the Youth of South Africa (Department of Education 2011). The growth phase of human rights education discourse in South Africa was therefore epitomised by an increased awareness of education about, in and for human rights (Struthers 2015). The growth phase was also characterised by research on the context which should be used to teach human rights, precisely what should to be taught, and how it should be taught (Carrim and Keet 2005; Du Preez 2008; Du Preez, Simmonds and Roux 2012).

In the age of global distrust in the human rights discourse, a cynical phase has emerged. This cynicism is the result of a 'disabling scepticism, even among those who admire its [human rights] motivating ideas' (Beitz 2009, 2). This scepticism stems partly from the inability to enforce human rights internationally because of hegemonic social realities (Dembour 2010). Furthermore, ' $[\mathrm{t}]$ he problem is that, although the idea and language of human rights have become increasingly prominent in public discourse, it has not become any more clear what kinds of objects human rights are supposed to be, why we should believe that people have them, or what follows from this belief for political practice' (Beitz 2009, xi). Typically, scholars in this phase have begun to question whether rights are indeed meant for those who suffer as a result of human rights violations or whether they are merely the prerogative of the privileged in society (Dembour 2010; Žižek 2005); or as Keet (2007) does in his thesis, question human 
rights research approaches as well as the inclusion of human rights education in general. This distrust, fuelled by an increasing cynicism about human rights, features in Keet's $(2015,48)$ later work again when he states that ' $[\mathrm{t}]$ he global distrust in human rights is not countered by HRE (human rights education) because such distrust is directed at the very understanding of human rights on which HRE is based'.

These phases enabled us to identify three key discourses shaping human rights education research in South Africa, namely human rights education through its inception and then its growth in South Africa and, more recently, a discourse that is cynical of human rights education. Next, we reflect on the possibilities that these findings reveal for future research.

\section{FUTURE CONSIDERATIONS FOR HUMAN RIGHTS EDUCATION RESEARCH}

Our review revealed two key findings: (1) the major focus of the human rights education research is predominantly school-based and (2) the research is fundamentally descriptive and uncritical.

Regarding the first finding: both internationally and nationally there has been a mindshift from situating human rights education only in the classroom for purposes of school-based teaching, learning and assessment. Human rights education has extended its research parameters within various contextual domains and for applicability within broader society. Internationally this has been cornerstone of the initiatives of the United Nations who recognise human rights education as 'a lifelong process that concerns all ages’ (United Nations 2011, 3). More specifically,

[h] uman rights education and training concerns all parts of society, all levels, including preschool, primary, secondary and higher education, taking into account academic freedom where applicable, and all forms of education, training and learning, whether in a public or private, formal, informal or non-formal setting. It includes inter alia vocational training, particularly the training of trainers, teachers and State officials, continuing education, popular education, and public information and awareness activities (ibid.).

Distinguishing the place of human rights education in the field of Education in this broadest sense further attests to the action plans implemented by the United Nations, in the form of world programmes. The first phase of this programme (2005-2009) focussed on the primary and secondary schooling system. The programme has since developed a second and third phase. The second phase (2010-2014) focussed on higher education, civil servants, law enforcement officials and the military. Currently, the third phase (2015-2019) is aimed at strengthening implementation of the first two phases and promoting human rights training for media professionals and journalists. 
In South Africa, the responsibility is still placed too heavily on schools to be the driving force of human rights education as highlighted by Mubangizi’s $(2015,512)$ findings that showed the direct role of human rights education is 'restricted to infusing elements of HRE into the GET and FET school curricula at primary and secondary schools'. This could be part of the reason why human rights education research in the field of Education remains confined to research on and for school-based education. One aspect of this challenge might lie with what constitutes the field of Education. Just as primary and secondary school constitutes the field of Education, the White Paper for Post-School Education and Training (Department of Education 2013) draws attention to the place of post-schooling within this field. The White Paper specifies technical and vocational education and training (TVET) colleges, community colleges and universities as three key post-schooling sectors which comply with the requirements of the South African Qualifications Authority (SAQA), education and training quality assurance institutions, and the National Qualification Framework (NQF). One of the key visions of the Department of Higher Education and Training (DHET) is to uphold 'a post-school system that can assist in building a fair, equitable, non-racial, non-sexist and democratic South Africa' (Department of Education 2013, 4). This notion is underpinned by the interplay of various intersecting dimensions such as access for success, institutional culture and management, epistemic access, and redressing equity (age, [dis]ability, race, gender and class) (Du Preez, Simmonds and Verhoef 2016). The White Paper elaborates:

The institutional landscape is still reminiscent of apartheid, with disadvantaged institutions ... in terms of infrastructure, teaching facilities and staffing. Black students at formerly whites-only institutions have often been victims of racism, and female students have been victims of patriarchal practices and sexual harassment. Poorer students have to fit in with systems that were designed for students from relatively privileged backgrounds ... The majority of disabled students continue to experience discrimination ... and the system as a whole has inadequate facilities and staff to cater for the needs of the disabled. Education for adults has been marginalised and neglected, and has seldom provided a vocational component for those seeking to enhance their occupational skills (Department of Education 2013, 1).

These struggles of access, support, racism, class, sexism, poverty, disability and age are not unique to post-schooling; schooling also encounters similar challenges. The South African Human Rights Commission (SAHRC), which was established in 1995, has taken great strides towards promoting human rights through social services, education and research across various sectors of society. In 2000 the SAHRC established a National Centre for Human Rights Education and Training (NACHRET) dedicated to '[t]he development of a sustainable culture of human rights by translating human rights standards into tangible and deliverable education and training outcomes' (South Africa 2001, 13). NACHRET focusses on developing the 
schooling and post-schooling sectors and as such reinforces the diverse scope of human rights education research.

We do not negate the importance of school-based human rights education research neither do we underscore the interdisciplinary human rights education research being promoted in other fields (sociology, law, theology and so on). Rather we are of the opinion that too little is done by human rights education researchers (especially doctoral candidates) in the field of Education to embrace the complexity of their field. Participating in wider (post-schooling) debates will expose researchers not only to the varying contexts at play but also to the applicability of the research findings for different sectors of the field of Education, giving their research greater relevance and reachability. In their analysis of human rights education research, Tibbitts and Kirchschlaeger (2010) argue for the need for research on comparative education, world polity theory, internationalisation debates, indigenous knowledge, transformative learning (critical and transgressive pedagogies), adult learning, and youth development. We encourage researchers to consider these, and other relevant topics, within human rights education postschooling research. In addition, we urge researchers to be more cynical when engaging in human rights education research so as to stimulate critical engagement with this research domain. This brings us to a discussion on our second finding.

The second finding revealed that researchers often uncritically accept the fundamental nature of human rights and how it influences the way human rights education is conceptualised. Possibly, these studies remain school-based and fundamentally descriptive and uncritical because many of the doctoral candidates approach the topic with a 'how-to-solve-the-problemmentality'. This mentality is the result of the hegemonic neo-liberal status quo that requires instant problem solving (Žižek 2012, 9-10). In the process, researchers align themselves with the private use of reason by becoming 'experts' who claim to be able to solve deep-rooted societal issues (Žižek 2013, 53-54). The problem here is that this phenomenon has created a situation where essential thinking and questioning have been subordinated to the need to provide instant solutions (Žižek 2013, 53). This discussion confirms that the hegemonic discourses of human rights education remain narrow and uncritical. As such, human rights education researchers need to question and research the arguments and discourses put forward by those who are cynical about human rights. This approach might reveal a critical, deconstructive perspective on the ontological and epistemological foundations of human rights so that evolutionary thoughts are stimulated and an alternative language is conceptualised to advance research in the field of human rights education. Both of these suggestions require the ability to interrogate. Žižek $(2012,18)$ encourages us to ask new, troubling and unpleasant 
questions such as: Is a particular social issue really a problem? Are we formulating the problem correctly? How did we arrive at this social problem? (Žižek 2013, 53). Žižek should be taken seriously when he says, 'It is the people who have the answers, they just do not know the questions to which they have (or, rather are) the answer' (2012, 89). As a result, those embarking on human rights education research should be heedful of the questions that they ask and avoid trying to solve problems with 'quick fixes'.

We find Žižek's critique of human rights stimulating in as far as it raises fundamental questions about human rights that might facilitate the development of an alternative language to advance the field of human rights education research and to inspire researchers to become more cynical about human rights education research that too often engages with the topic uncritically. In an article, Against human rights, Žižek (2005) provides a provocative, albeit convincing argument about human rights in liberal capitalist democracies. For him, three assumptions underpin contemporary appeals to human rights in liberal capitalist democracies: the first is that such appeals function in opposition to modes of fundamentalism that would naturalise or essentialise contingent historically conditioned traits. The second is that the two most basic rights are freedom of choice, and the right to dedicate one's life to the pursuit of pleasure (rather than to sacrifice it for some higher ideological cause). The third assumption is that an appeal to human rights may form the basis for a defence against the 'excess of power' (Žižek 2005, 115).

Regarding the first point, Žižek (2005, 116-117) argues that liberal capitalist democracies use the features of fundamentalism - i.e. religious intolerance, ethnic violence and a fixation with historical trauma - to divert attention to the private sphere where difference prevails. In so doing, the public sphere is fragmented and weakened, thus more power is bestowed upon liberal capitalist democracies to decide on the behalf of the public who are fragmented and unequal in nature (Žižek 2005, 117). It is in this sense that Žižek $(2013,39)$ also refers to the disappearance of public life. Drawing on Catherine Malabou's The New Wounded, Žižek (2013, 56-57) explains the loss of public life as a new psychic illness, namely 'post-traumatic personality', where the individual has experienced trauma and is deprived of social existence and substance.

On the second point, Žižek (2005, 117-118) challenges pseudo-choices: when we are given the freedom of choice, but in a context where the conditions under which the choice is to be made renders it unfree. Elsewhere Žižek $(2012,54)$ rhetorically asks: What world do we inhabit in which we celebrate freedom of choice but see blind acting out as the only response to enforce democratic consensus? Together with this goes a redoubled right of seeking pleasure by duty and seeing one’s duty as pleasure. Žižek (2005, 120-121) describes this as follows: 
In the first case, pleasures are my duty, and the 'pathological' striving for pleasure is located in the formal space of duty. In the second case, duty is my pleasure, and doing my duty is located in the formal space of 'pathological' satisfactions.

This logic drives humans to both obey and exploit human rights, which inevitably sustains liberal capitalist democracies.

Regarding the third point, Žižek (2005, 121-125) postulates that liberal capitalist democracies hide the violence inherent to their power by employing the language of human rights. For example, they will tolerate moral wars between populist/conservative parties and liberalist parties on human rights issues such as homosexuality and abortion, merely to protect their own economic and political interests through reinforcing difference in the private sphere so as to weaken the strength of public reason (Žižek 2012, 30-32). Tolerating such moral wars is an example of politically correct behaviour: behaviour that 'hides extreme violence' (Žižek 2013, 84). In addition, by tolerating moral wars through emphasising morality through the language of human rights, liberal capitalist democracies divert the discourse to prevent a critique against neo-liberalism (Žižek 2012, 78).

Against this background, Žižek (2005, 125-128) problematises how liberal capitalist democracies both depoliticise human rights and humanise them. The former happens when dominant forces are put in place to restore the rights of the deprived, exploited or powerless humans. Such interventions, he argues, are used to depoliticise and mask liberal capitalist democracies' economic and political interests. The latter occurs when human rights are treated as a commodity: when they are handed over from those with power (should they not use their rights) to those left powerless. Commodifying human rights is theoretically justified by universalist/particularist essentialisations that ascribe very different meanings to what constitutes 'human'. In addition, it leads to the question: What do human rights mean for those treated as human and what does it mean for those suffering inhumanness?

For Žižek $(2005,131)$ the gap between the depoliticisation and humanisation of human rights discourses is not merely an abstract paradox, but a concrete one in as far as it 'separates the whole of the community from itself'. He argues that the discourses steering human rights in liberal capitalist democracies can only be changed and regenerated when the symbolic gap between these discourses is understood as a space where this reconceptualisation could take place (Žižek 2005, 128). This gap is not to be filled or balanced in any way, because these discourses already flow into one another, thus affirming the varied identities that emphasise their difference (Žižek 2013, 5). By way of illustration, Žižek (2012, 15) argues that the instability of capitalism creates a double symptomatic threat that leads to solutions such as resuscitating social solidarity and emphasising multicultural tolerance, but fails to address the 
deep-seated issues in the existing order. Therefore, he warns us not to attempt to humanise the capitalist beast (Žižek 2012, 16). What is in fact needed is a change in the balance, that is, when the measure of balance can be reformed to change the existing order (Žižek 2013, 7).

\section{CONCLUSION}

This article suggests that the discourses shaping human rights education research have been marked by three phases: the inception, growth and cynicism in the field of Education in South Africa. Based on the pleas to envisage human rights education as 'a space for contestation, contention, disputation, public debate and social engagement' (Keet 2012, 9), we have put forth two considerations for researchers. These are based on our findings that current research is predominantly school-based and fundamentally descriptive and uncritical. First, we do not regard it fruitful that in South Africa the responsibility is still placed too heavily on schools to be the driving force of human rights education. More research on and in post-schooling will initiate broader human rights education debates that will enrich the field of Education. Second, we question research that uncritically accepts the fundamental nature of human rights as this reinforces the way human rights education is conceptualised. We encourage researchers in human rights education to challenge and research the arguments and discourses put forward by those who are cynical about human rights.

\section{NOTE}

1. We acknowledge the differences between human rights education and human rights in education and are also aware of the various nuances to which these give rise. For the purpose of this article the concept 'human rights education' is used as a collective so as to include all variances.

\section{REFERENCES}

Alston, K. S. 2002. The constitutional right to freedom of expression: An exploration of its relevance to the South African school community. Ph.D. thesis, University of the Free State, Bloemfontein.

Asmal, K. and W. James. 2002. Spirit of the nation. Reflections on South Africa's educational ethos. Cape Town: HSRC.

Beitz, C. 2009. The idea of human rights. Oxford \& New York: Oxford University Press.

Carrim, N. and A. Keet. 2005. Infusing human rights into the curriculum: The case of the South African revised national curriculum statement. Perspectives in Education 23(2): 99-101.

Chingono, M. and S. Nakana. 2009. The challenges of regional integration in Southern Africa. African Journal of Political Science and International Relations 3(10): 396-408.

Dembour, M. B. 2010. What are human rights? Four schools of thought. Human Rights Quarterly 32(1): $1-20$.

Department of Education. 1996. South African schools act no. 84 of 1996. http://www.education.gov.za/LinkClick.aspx?fileticket=aIolZ6UsZ5U\%3D\&tabid=767\&mid=3 184 (accessed 15 February 2017). 
Department of Education. 1997. Education white paper 3. A programme for the transformation of higher education. Government Gazette, vol. 390, no. 18515. Pretoria: Government Printers.

Department of Education. 2001a. Education white paper 6. Special needs education. Pretoria: Government Printers.

Department of Education. 2001b. The national conference: Saamtrek: Values, education and democracy. Pretoria: Government Printers.

Department of Education. 2001c. Manifesto on values, education and democracy. Pretoria: Government Printers.

Department of Education. 2002. School-based research report on values, education and democracy. Pretoria: Government Printers.

Department of Education. 2003a. The framework on values and human rights in the curriculum. Pretoria: Government Printers.

Department of Education. 2003b. Improving access to free and quality basic education for all. Pretoria: Government Printers.

Department of Education. 2005. Values and human rights in the curriculum: A guide. Pretoria: Government Printers.

Department of Education. 2011. Bill of responsibilities for the youth of South Africa. Pretoria: Government Printers.

Department of Higher Education and Training. 2013. White paper for post-school education and training. Pretoria: Government Printers.

De Wet, A. 2014. Education law research: Two sides of a coin. Education Law Journal 1: 29-41.

Du Preez, P. 2008. Dialogue as facilitation strategy: Infusing the classroom with a culture of human rights. Ph.D. thesis, Stellenbosch University, Stellenbosch.

Du Preez, P. 2012. The human right to education, the ethical responsibility of curriculum, and the irony in 'Safe Spaces'. In Safe spaces: Human rights education in diverse contexts, ed. C. Roux, 51-62. Rotterdam: Sense Publishers.

Du Preez, P., S. Simmonds and C. Roux. 2012. Teaching-learning and curriculum development for human rights education: Two sides of the same coin. Journal of Education 55: 83-103.

Du Preez, P., S. Simmonds and A. Verhoef. 2016. Rethinking and researching transformation in higher education: A meta-study of South African trends. Transformation in Higher Education 1(1): 1-7. http://dx.dio.org?10.4102/the.v1i1.2

Gamede, T. 2005. The biography of 'access' as an expression of human rights in South African education policies. Ph.D. thesis, University of Pretoria, Pretoria.

Gammage, C. 2014. Protecting human rights in the context of free trade? The case of the SADC group economic partnership agreement. European Law Journal 20(6): 779-792.

Gibson, J. 2004. Does truth lead to reconciliation? Testing the causal assumptions of the South African truth and reconciliation process. American Journal of Political Science 48(2): 201-217.

Joubert-Serfontein, E. M. 2007. The fundamental rights of learners within inclusive education: An educational-juridical perspective. Ph.D. thesis, North-West University, Potchefstroom.

Keet, A. 2007. Human rights in education or human rights education: A conceptual analysis. Ph.D. thesis, University of Pretoria, Pretoria.

Keet, A. 2012. Discourse, betrayal, critique. The renewal of human rights education. In Safe spaces: human rights education in diverse contexts, ed. C. Roux, 7-27. Rotterdam: Sense Publishers.

Keet, A. 2014. Refractions: Social theory, human rights and philosophy. Acta Academica 46(4): 132158.

Keet, A. 2015. It is time: Critical human rights education in an age of counter-hegemonic distrust. Education as Change 19(3): 46-64. 
McCowan, T. 2010. Reframing the universal right to education. Comparative Education 46(4): 509525.

Mubangizi, J. 2015. Human rights education in South Africa: Whose responsibility is it anyway? African Human Rights Law Journal 15: 496-514.

Ndlala, M. W. 2002. The teacher's legal right to professional development. Ph.D. thesis, University of Pretoria, Pretoria.

Netshitahame, N. 2008. An analysis of learners' knowledge and understanding of human rights in South Africa. Ph.D. thesis, University of Pretoria, Pretoria.

South Africa. 2000. South African council for educators act. https://www.sace.org.za/ (accessed 15 February 2017).

South Africa. 2001. South African human rights commission $5^{\text {th }}$ annual report January 2000 - March 2001. Pretoria: Government Printers.

Struthers, A. E. C. 2015. Human rights education: Educating about, through and for human rights. The International Journal of Human Rights 19(1): 53-73.

Suarez, D. and F. Ramirez. 2004. Human rights and citizenship: The emergence of human rights education. Working papers, Number 12. Center on Democracy, Development, and the Rule of Law, Stanford Institute for International Studies.

Tibbitts, F. and P. G. Kirchschlaeger. 2010. Perspectives of research on human rights education. Journal of Human Rights Education 2(1): 1-31.

United Nations. 2011. Proposed draft declaration on human rights education and training as prepared by the platform for human rights education and training. https://documents-ddsny.un.org/doc/UNDOC/GEN/G11/104/25/PDF/G1110425.pdf?OpenElement (accessed 15 February 2017).

Van Vollenhoven, W. 2006. Learners' understanding of their right to freedom of expression in South Africa. Ph.D. thesis, University of Pretoria, Pretoria.

Viljoen, J. C. H. 1999. Die invloed van ' $n$ menseregtekultuur op die skoolhoof se bestuurstyl (The influence of a culture of human rights on the management style of the school principal). Ph.D. thesis, Rand Afrikaans University, Johannesburg.

Žižek, S. 2005. Against human rights. New Left Review 34 (July/August): 115-131.

Žižek, S. 2012. The year of dreaming dangerously. London: Verso.

Žižek, S. 2013. Demanding the impossible, ed. Y. Park. Cambridge: Polity. 